\title{
The relationships among love of money and unethical behaviour
}

Farieza Rahman

PT. TASPEN (Persero), Jakarta, Indonesia

fariezarahman@gmail.com 


\title{
The relationships among love of money and unethical behaviour
}

\author{
Farieza Rahman
}

PT. TASPEN (Persero), Jakarta, Indonesia

JEL Classification:
G40, D63
Keywords:
love of money, Machiavellianism,
narcissism, unethical behaviour.

${ }^{*}$ Corresponding Author:

fariezarahman@gmail.com

DOI:

10.20885/jca.vol2.iss3.art3

Copyright @2020

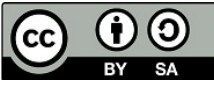

This is an open access under CC-BY-SA LICENSE

\begin{abstract}
This study examines the relationships between love of money and unethical behaviour, with Machiavellianism and narcissism, acted as the intervening variables. The data were collected by distributing a questionnaire to 122 banking employees in Yogyakarta and analysed using multiple regression analysis to test the hypothesis. Results indicate that Machiavellianism and narcissism were significantly related to unethical behaviour. Meanwhile, instead of love of money, which did not have any relationship with Machiavellianism, it had a significant relationship with narcissism. The implication of the findings is that a person who loves money and with high Machiavellianism are more likely to do unethical behaviour. However, people with high love of money are not always associated with a Machiavellianism personality.
\end{abstract}

\section{Introduction}

The increasing prevalence of globalisation puts accountants as a profession in need as the key to global business practices as an accountant has become an excellent corporate governance catalyst. Throughout transactional an economy still exist and uses the money as legal tender, the role of accounting is always crucial for the accounting record of all business events of a financial nature (Sumartono et al., 2020). As an accountant has become a highly needed profession, it requires more attention to ethics and professionalism. The high professionalism of an accountant produces high quality in their work (Hamdani et al., 2020). On the contrary, society nowadays starts questioning the professionalism and ethical behaviour of professional accountants and accountants in large companies due to their financial cases and scandals. This situation leads to the downfalls of public trust for professional accountants in general. It shows no ethics in the professional accountants who are involved in the business field.

Individuals' attitude towards money or wealth is an issue that has been evaluated since almost human being. The high passion for money affects a person's behaviour, and it can lead to unethical behaviour intention as people realise how vital money for their life. Tang and Liu (2012) found that in the presence of an ethical and higher-character supervisor, an employee with significant love of money was likely to obey authority figures and do what is ethically right. However, in the presence of an unethical supervisor, high love of money individuals could not resist temptation and would behave unethically.

Gurlek (2021) studied the relationship between e relationships between Machiavellianism, career ambition, and unethical behaviour intention. The study revealed that Machiavellianism positively correlates with unethical behaviour intention. Accordingly, it is put forward that individuals embracing the understanding that it is legitimate to display unethical behaviour to reach their ultimate goal have higher intentions of engaging in unethical behaviour. Machiavellianism was proven to affect individual unethical behaviour directly. Someone with a trait of Machiavellianism 
tends to focus on their ambition and interests, manipulative and aggressive. Machiavellianism tendencies are commonly found in business sectors, especially accounting.

Despite Machiavellianism, narcissism has also become another factor that affected individual unethical behaviour. Narcissism is widely portrayed as an exaggerated feeling of superiority, a high level of self-centeredness and self-love (Djeriouat \& Trémolière, 2014). In psychoanalysis, narcissism portraits immature personality. Therefore, narcissism is considered a personality disorder that leads to the inability to adapt to people. People, especially accountants, who have this personality disorder, tend to adopt unethical behaviours.

This study is aimed at testing the relationship between love of money and unethical behaviours. Previous studies had been conducted more on psychological and managerial aspects, and not many studies discuss how love of money affects accountants' unethical behaviours. Besides, this study analyses how Machiavellianism and narcissism act as mediators to the relationship between love of money and unethical behaviour. Results show that Machiavellianism and narcissism have a significant effect on unethical behaviours. Also, narcissism has been a fair mediator of love of money and unethical behaviours even though there was no evidence for the effect of love of money on Machiavellianism.

\section{Literature Review}

\section{Theory of Reasoned Action}

The theory of reasoned action (TRA) is derived from the theory of planned behaviour. This theory tries to differentiate behaviour and behaviour intention. Behaviour intention is the reason behind behaviours, and when individual acts based on the reason is called behaviours. TRA explains that behaviour intentions are entirely under the control of the individual (volitional behaviour). This theory suggests that each individual is aware of their actions in performing behaviours if they have the intentions (Jalil et al., 2019). The theory of reasoned action was considered the best-known theory for measuring unethical intention. The major goal of TRA is to predict and understand an individual's behaviour and posits that an individual's intention to perform (or not to perform) the behaviour is the immediate determinant of behaviour.

The theory of reasoned action is a model which proposes that the prediction of an individual's behaviour in a particular situation can be explained. Two self-determining intentions are hypothesized by this theory. Firstly, is the attitude towards the bebaviour, which is either a positive or negative appraisal of the individual's behaviour and secondly, the subjective norm; a social factor, which relates to the presumed social demand to perform or not to perform the behaviour (Khan et al., 2013). In the context of unethical behaviour, the theory hypothesizes that unethical behaviour can be determined by an individual's behavioural intention to accept that unethical behaviour. It can be followed by focal constructs in this theory, the attitude toward behaviour to perform, and subjective norm. Thus, the theory of reasoned action establishes these causal relationships existing between attitudes, intentions, and behaviours.

\section{Love of Money}

Money attitudes and behaviours are explained on the basis of the feeling of individuals towards money that is a motivator as well as success, importance and wealth symbols. A growing body of individuals thought that money is a motivation tool and money symbolizes success and money is important to be rich. Love of money is a person's behaviour on money and one's wishes and aspirations for money (Khanifah et al., 2019). In some cases, love of money becomes a variable for employee recruitment to check their ethical perception. Employees with a love of high money will be motivated to work as much as possible to fulfil their desires for money so that when employees feel that their love of money has been fulfilled, their work ethic will increase which directly enhances the performance of employees. 
Some studies investigated the effect of love of money in a business context and reported some fraudulent practices caused by employees' money orientations. It shows that love of money has a significant relationship to unethical behaviour. People who are susceptible to money's temptation tend to perform unethical behaviours (Yeltsinta \& Fuad, 2013). Liu and Tang (2011) research has also found results that love for money (high love of money) has a positive effect on employee motivation to work. The higher the ethics that is owned, the level of love for the money he has tends to be lower (Elias \& Farag, 2010). Demographic factors such as age, sex, education, social-economic status and work experience influence the individual money orientation and love of money.

\section{Machiavellianism}

Machiavellianism was firstly introduced by Italian political philosophy Niccolo Machiavellian (14691527). Then, it is negatively associated with fraudulent and manipulative manners in achieving goals. Brewer (2017) describes Machiavellianism is characterised by a manipulative interpersonal style, willingness to exploit others, and a preference for emotionally detached relationships Highly Machiavellian individuals may aggressive and deviant methods to achieve their goals, regardless of other people's feelings, rights and needs (Gu \& Wen, 2017). Machiavellianism personality displays tendencies to manipulate people and show less appreciation to people. Therefore, it is often attributed to manipulative individuals who use persuasion to achieve their personal goal and aggressive ambition.

\section{Narcissism}

Narcissism is widely portrayed as an exaggerated feeling of superiority, a high level of selfcenteredness and self-love (Djeriouat \& Trémolière, 2014). It is useful to think of narcissism as containing three components: the self, interpersonal relationships and self-regulatory strategies. First, the narcissistic self is characterized by positivity, "specialness" and uniqueness, vanity, a sense of entitlement and a desire for power and esteem. Second, narcissistic relationships contain low levels of empathy and emotional intimacy. In their place, there are (often numerous) shallow relationships that can range from exciting and engaging to manipulative and exploitative. Third, there are narcissistic strategies for maintaining inflated self-views. For example, narcissists seek out opportunities for attention and admiration, brag, steal credit from others, and play games in relationship (Campbell et al., 2011).

Another alternative explanation for narcissism highlights the urge of becoming superior to other people. Narcissistic individuals feel superior to others, fantasize about personal successes, and believe they deserve special treatment. When they feel humiliated, they often lash out aggressively or even violently (Brummelman et al., 2015). Further, it creates the degree of their selfesteem. "Diagnostic and Statistical Manual of Mental Disorders" by the American Psychiatric Association (2013) lists characteristics of narcissistic personality disorder in the following:

1. Has excessive self-importance

2. Obsesses with fantasies of unlimited success, power, beauty, or perfect love.

3. Requires recognition from people as superior, special, and unique

4. Requires excessive admirations from people

5. Expects people to give them favourable treatment and have unrealistic expectations

6. Is exploitative and takes advantage of others to achieve their goals

7. Lacks empathy for people

8. Is envious of others or believes that others are envious of them

9. Displays arrogance, violence, haughty behaviours to others

\section{The Effect of Love of Money on Machiavellianism}

Love of money reflects an individual attitude toward wealth and motivation to earn money. Machiavellian personality is a construct that influences people to perform unethical behaviours and 
stimulate the difference of ethical behaviours (Yendrawati \& Witono, 2011). Machiavellianism displays incitement, aggressive, manipulative, exploitative and devious behaviours to achieve personal goals. TRA explains that intentions influence individual behaviours. When people desire to possess enormous wealth, they are prone to perform Machiavellian personality in achieving their goals. A previous study conducted by Pekdemir and Turan (2015) stated that individuals being very much fond of money were more likely to represent upper level Machiavellian personality than individuals being very little fond of money. Following the explanation above, the researcher proposes the following hypothesis:

$\mathbf{H}_{1}$ : Love of money has a positive effect on Machiavellianism

\section{The Effect of Machiavellianism on Unethical Behaviours}

Studies investigating characters of Machiavellianism personality suggest that Machiavellianism is an influential variable that significantly affects ethical perspective. Bulutoding et al. (2017) found that Machiavellianism personality had adverse and significant effects on ethical behaviours. It means that people with high Machiavellianism tend to have poor ethical behaviour. On the contrary, people with low Machiavellianism tend to have high ethical behaviours. Strong Machiavellianism personality creates manipulative, persuasive, and fraudulent behaviour for people in achieving goals.

TRA explains that subjective norms influence people's behaviours so that the basis of people behaviours is affected by behaviour intention. It then influences people to perform behaviours. A Machiavellian individual tends to manipulate and control other people (Friscilla \& Nugroho, 2020). Thus, a Machiavellian individual can influence other Machiavellian individuals to engage in ethical or unethical behaviours as Rindayanti and Budiarto (2017)state that Machiavellianism affects an individual's ethical perception. People attempt to reconceptualise ethical decision when they encounter any situation which requires social responsibility. Machiavellian personality might appear, when needed, to help to achieve goals by violating ethics. Thus, the researchers propose the following hypothesis;

$\mathbf{H}_{2}$ : Machiavellianism has a positive effect on unethical behaviours

\section{The Effect of Love of Money on Narcissism}

Individual financial possession can lead to self-importance. Narcissistic individual use wealth such as money, assets and possessions as tools to show their superiority. The individual mindset and behaviour could be linked to the aspect of maladaptive narcissism (de la Peña, 2019). In this case, love of money and narcissism are predicted to have a positive relationship which means an individual with a higher love of money will have a more assertive narcissism personality and vice versa. Providing individual needs, by all means, contributes to a high love of money, leading to selfimportance, excessive self-admiration, and obsessive craving for affirmation. Following the explanation above, the researcher proposes the following hypothesis:

$\mathbf{H}_{3}$ : Love of money has a positive relationship with narcissism

\section{The Effect of Narcissism on Unethical Behaviours}

Nugraheni and Wahyuni (2016) confirm the positive effect of narcissism on the counter productive behaviours of employees. Dimensions of narcissism personality include authority, superiority and high self-worth. Narcissists are extremely sensitive to criticism and react negatively to feedback. They consider social interaction as being dominant over other people. Narcissists need constant input for their ego, so they demand anything in line with their wishes. Anything that threatens their ego is met with negative emotions and even rage. The result of those negativities often become unethical behaviours (Nugraheni \& Wahyuni, 2016). Narcissism is considered as a disorder by the presence of obsessive craving for affirmation. The higher narcissists crave for admirations, the higher their risks to engage in unethical behaviours (Korompis \& Latjandu, 2017; and Analisa, 2020). Following the explanation above, the researcher proposes the following hypothesis: 
$\mathbf{H}_{4}$ : Narcissism has a positive relationship with unethical behaviours

\section{The Effect of Love of Money on Unethical Behaviours}

The love of money reflects the degree of love related to money and how people consider the importance of money in their life. Excessive interest in money tends to affect people's decisionmaking, and they tend to decide on everything based on money. High love of money on students affects their ethical perceptions negatively (Prabowo \& Widanaputra, 2018). Farhan et al. (2019) state that people with high love of money tend to perform unethical behaviours, including tax embezzlement. Giovano et al. (2020) confirm that love of money can be attributed to fraud accounting. People with high love of money has a high money orientation as the basis of their interest and desire, which leads them to have the tendencies to perform unethical behaviours and become more sensitive compared to people with low love of money. Thus, it impacts on tax embezzlement tendency that is personally detrimental. Following the explanation above, the researcher proposes the following hypothesis:

$\mathbf{H}_{5}$ : Love of money has a positive effect on unethical behaviours

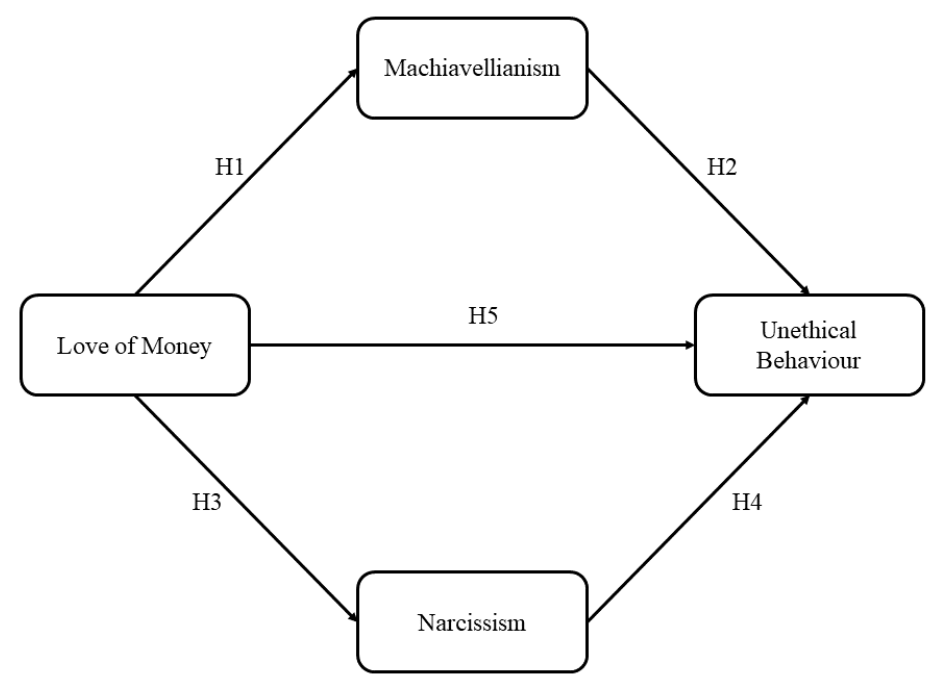

Figure 1. Research Model

\section{Research Method}

This research used primary data collected directly from the source. The data were collected by using field research by distributing a questionnaire. The questionnaire was aimed to collect primary data from conventional bank employees as the participant in this research. The researcher adopted convenience sampling, which provides convenience in the data collection procedure. The samples consisted of the head of a division, head on sub-division, head of a section, head of unit and finance staff of the banking sector in Yogyakarta.

\section{Data Analysis Method}

The hypotheses were tested by using regression analysis and Structural Equation Model (SEM) approach. SEM is multiple statistical analysis techniques used to analyse complex structural relationships simultaneously. Smart PLS 3.0 was used in this research to analyse SEM research based on variance. This type of data analysis is loose but powerful since it does not require many assumptions (Ghozali \& Latan, 2015). PLS is used for two sub-model data analysis, including the measurement and structural models. Table 1 shows the steps of the measurement test for each model and accepted standard value. 
Table 1. Stages of Measurement Model Test

\begin{tabular}{lll}
\hline Stage & Type of measurement & Prerequisite value \\
\hline Validity test & - AVE value & $>0.5$ \\
Convergent & - Item Loading value & $>0.5$ \\
\hline Validity test & AVE square root value & $\begin{array}{l}\text { AVE square root is more prominent } \\
\text { than construct correlation matrix }\end{array}$ \\
Discriminant & & $>0.7$ \\
\hline Reliability test & Composite Reliability value & \\
\hline
\end{tabular}

The inner model measurement used for significant measurement between construct in the structural model can be seen using R-square to test the significance of independent variable to the dependent variable and path-coefficients or t-values of each path (Hartono \& Abdillah, 2015).

\section{Results and Discussions}

\section{Characteristics of Respondents}

The researcher collected data from 122 participants. Out of 122 respondents, 58 respondents $(47.5 \%)$ were in their $30 \leq 40$ years old, 65 female respondents $(53.2 \%)$ and 57 male respondents (46.8\%). Data based on their educational background revealed that most of the respondents had bachelor degrees $(80.3 \%)$. Also, data regarding their working experience revealed that the highest percentage $(44.3 \%)$ of the respondents worked for $0-5$ years in their organisations.

\section{Outer Model Measurement}

\section{Validity test}

Convergency validity and discriminant validity were used in this research for the validity test. Convergency validity from the reflective measurement model is tested based on the correlation between item values or score component using Smart PLS 2.0 M3. For the reflective model, one can expect the construct's correlation to be high if the value is more than 0.70 . However, for the initial stage of the research of the development measurement scale, a loading value of 0.50 to 0.60 is considered sufficient (Ghozali \& Latan, 2015). The initial stage of convergent validity measurement showed that the construct indicator's outer loading received a value of more than 0.50. According to the measurement, all items of the loading factor were valid.

\section{Reliability test}

Reliability measures the internal consistency and constructs indicator, which shows the degree to which the indicators present a general construct. The generally accepted value of reliability is 0.70 . A construct that can be categorised as reliable is the reliability test has a value of 0. (Ghozali \& Latan, 2015). In this study, the reliability test can be seen in the composite reliability value. Table 2 presents the items used to test unethical behaviour, Machiavellianism, narcissism, love of money received reliability composite by the value of $>0.70$. Therefore, it can be concluded that all constructs in this study were reliable.

Table 2. Composite Reliability Value

\begin{tabular}{ll}
\hline Variable & Composite Reliability \\
\hline Unethical behaviours & 0,8393 \\
Machiavellianism & 0,7771 \\
Narcissism & 0,9283 \\
Love of Money & 0,9376 \\
\hline
\end{tabular}




\section{Inner Model Measurement}

This research used multiple regression analysis with Smart PLS 2.0 M3 to test the hypotheses. The result of inner weight showed the result of the five hypotheses tested. If the original sample estimate's coefficient value shows a positive value, the result shows a positive relationship and vice versa. To find out the effect between variables, the research compared the t-statistics value with the t-table. According to Ghozali and Latan (2015), the formula t-table value is (N-K), in which $\mathrm{N}$ is the number of respondents, and $\mathrm{K}$ is the number of variables.

Based on the formula, the t-table value was 1.660. It was calculated from the reduction of 122 (respondents) with 4 (variables), and the result was 118 . For one-tail distribution with $\alpha 5 \%$ and $\alpha 10 \%$, for row 100 (within 100-1000 in the t-table) found the value of t-table in $\alpha 5 \%$ was 1.660 and $\mathrm{t}$-table for $\alpha 10 \%$ was 1.290 . If the t-statistics value is higher than the $\mathrm{t}$-table value, it shows a significant effect between variables. The result of the hypotheses test is in the following table.

Table 3. Hypotheses Test Result

\begin{tabular}{llll}
\hline Item & Path Coefficients & T-Statistic & \multicolumn{1}{c}{ Notes } \\
\hline LOM $\rightarrow$ Mach & 0.1584 & 0.7816 & $\mathrm{H}_{1}$ not supported \\
Mach $\rightarrow$ Unethical behaviours & 0,2110 & $5,7969^{* *}$ & $\mathrm{H}_{2}$ supported \\
LOM $\rightarrow$ Narcissism & 0.5061 & $5,9512^{* *}$ & $\mathrm{H}_{3}$ supported \\
Narsis $\rightarrow$ Unethical behaviours & 0,2350 & $2,0701^{* *}$ & $\mathrm{H}_{4}$ supported \\
LOM $\rightarrow$ Unethical behaviours & 0.1524 & $1.3207^{*}$ & $\mathrm{H}_{5}$ supported \\
\hline
\end{tabular}

Notes: ${ }^{*} \mathrm{p}<0.1 ;{ }^{* *} \mathrm{p}<0.05 ;{ }^{* * *} \mathrm{p}<0.01$

\section{Discussions}

\section{The effect of love of money on Machiavellianism}

The result of the first hypothesis testing shows no correlation between love of money and Machiavellianism. This result of the study is different from a study conducted by Pekdemir and Turan (2015). Theory Reasoned of Action highlights the fundamental value of love of money which consider higher than Machiavellianism. This theory correlates belief, attitude, intention and behaviours. One can predict the individual behaviours through their intention, and intention plays an important role as the best predictor. The accountant with a love of high money will be motivated to work as much as possible to fulfill their desires for money so that when employees feel that their love of money has been fulfilled, their work ethic will increase which directly enhances the performance of employees. On the other hand, an individual with Machiavellianism tends to create manipulative, persuasive, and fraudulent behaviour for people in achieving goals.

The implication of this result is people with high love of money is not always associated with a Machiavellianism personality. Individuals are going to love money (high love of money) in order to motivate them in work, so they are more likely to do an ethical behaviour.

\section{The effect of Machiavellianism on unethical behaviours}

The second hypothesis testing shows a significant positive influence of Machiavellianism on unethical behaviours. This result indicates that the higher the Machiavellianism personality, the higher the possibility of performing unethical behaviours as Machiavellianism is often associated with manipulative, persuasive, and aggressive individuals when it comes to achieving their personal goals. Other researches also share similar results from Friscilla and Nugroho (2020) and Rindayanti and Budiarto (2017), which confirm the positive effect of Machiavellianism on unethical behaviours. Machiavellianism tend to trigger unethical behaviours due to the individual's manipulative and aggressive characteristics, which then lead to moral disengagement. This finding implies that individuals who consider displaying unethical behavior (Machiavellianism) to achieve their desired goals as a normal action have a higher propensity to engage in unethical behavior. 


\section{The effect of love of money on narcissism}

The third hypothesis testing result shows the significant positive influence of love of money on narcissism, which indicates the higher love of money of an individual, the higher the narcissism level. Money is indeed paramount for human life; even people in the US regard money and wealth as a success parameter. Money is an aspect whose existence cannot be separated in life. Because money is very important. With money, someone can fulfill their needs, namely clothing, food, and shelter (Khanifah et al., 2019). If people have a high love of money, they tend to perform everything that can help them in fulfilling their needs and, in the end, will give them more self-importance. This personality leads to arrogancy, self-admiration and excessive need for people's appreciation. The implication of this finding is that individuals who love for money are the individuals who feel superior to others, fantasize about personal successes, and believe they deserve special treatment.

\section{The effect of narcissism on unethical behaviours}

The result of the fourth hypothesis testing shows a significant positive influence of narcissism on unethical behaviours. From this result, it can be concluded that the higher narcissism of an individual, the higher the tendencies to perform unethical behaviours. This result shows a similarity with previous research conducted by Nugraheni and Wahyuni (2016) and Korompis and Latjandu (2017), which confirm the significant effect between narcissism and unethical behaviour. Narcissism is considered a personality disorder that refers to the minimum adaptation of an individual to one another. This personality disorder may affect human behaviours and trigger unethical behaviours.

Nugraheni and Wahyuni (2016) mention that individuals with narcissism have high selfpride; they tend to have superiority and inflated ego, which makes them extremely hard to accept criticism even with factual and accurate information. When receiving threat, narcissists tend to react negatively, and those reactions trigger unethical behaviours. The implication of this result is a person with narcissism tend to make exaggerated claims of their abilities and performance, and it can lead to unethical behaviour.

\section{The effect of love of money on unethical behaviours}

Testing on the fifth hypothesis shows the positive effect of love of money on unethical behaviours. This result is in line with the previous research conducted by Farhan et al. (2019), Giovano et al. (2020), and Prabowo and Widanaputra (2018), which state the significant positive effect of love of money on unethical behaviours. People who put money as the most important aspect in life tend to high love of money personality. They are willing to perform any strategies to help achieve money orientation goals, including having shortcuts such as performing fraud. Fraudulence at work happens because of individual money orientation and tendency to perform anything to achieve their desire for money. It strongly proves the influence of love of money on the unethical behaviours of an individual. People who become subject to temptation tend to perform ethical or unethical behaviours.

The implication of this finding is that individuals thought that money is a motivation tool and money symbolizes success and money is important to be rich, when the deviation is one step to meeting the needs of getting money, people will justify their cheating easily. People who are subject to all kinds of temptations trigger them to behave ethically or unethically.

\section{Conclusion}

The purpose of this study is to analyse the effect of love of money on unethical behaviour with Machiavellianism and narcissism acted as the intervening variables. The result shows that Machiavellianism and narcissism are proved to have a significant effect on unethical behaviours. It can also be seen from this result that narcissism acts as the mediator of love of money and unethical behaviours. However, there is no correlation proved through this study regarding the effect of love of money on Machiavellianism. 
This study has the limitation that needs further research to add more knowledge about this subject area. The limitation includes the small scale of respondents in this study and the limited research area scope, which only involves the Special Region of Yogyakarta. There is also a possible bias in the data collecting method through questionnaire distribution. The bias lies in the subjectivity of the participants' responses. It is recommended to add and expand the research sample to enrich the data. Since this research focuses on the consequence of the love of money as the variable, further research needs to investigate the antecedent variable of love of money. Moreover, it is suggested to investigate personality variables besides Machiavellianism and narcissism, for example, the need for achievement and need for power.

\section{References}

American Psychiatric Association. (2013). Diagnostic and Statistical Manual of Mental Disorders (DSM-5) (5th ed.). American Psychiatric Publishing.

Analisa. (2020). Factors influencing unethical behaviour in banking industry. Journal of Contemporary Accounting, 2(2), 97-107. https://doi.org/10.20885/jca.vol2.iss2.art4

Brewer, G. (2017). Machiavellianism, relationship satisfaction, and romantic relationship quality. Europe's Journal of Psychology, 13(3), 491-502.

Brummelman, E., Thomaes, S., Nelemans, S. A., Castro, B. O. de, Overbeek, G., \& Bushman, B. J. (2015). Origins of narcissism in children. Proceedings of the National Academy of Sciences, 3659-3662.

Bulutoding, L., Paramitasari, R. D. A., \& Harun, F. (2017). Pengaruh sifat machiavellian dan love of money terhadap perilaku tidak etis auditor. Jurnal Ilmiah Akuntansi Peradaban, 3(2), 114-131.

Campbell, W. K., Hoffman, B. J., Campbell, S. M., \& Marchisio, G. (2011). Narcissism in organizational contexts. Human Resource Management Review, 21(4), 268-284.

de la Peña, D. (2019). Loving thyself and well-being: What does god have to do with it? The Journal of Faith, Education, and Community, 3(1), 1-30.

Djeriouat, H., \& Trémolière, B. (2014). The dark triad of personality and utilitarian moral judgment: The mediating role of Honesty/Humility and Harm/Care. Personality and Individual Differences, 67, 11-16.

Elias, R. Z., \& Farag, M. (2010). The relationship between accounting students' love of money and their ethical perception. Managerial Auditing Journal, 25(3), 269-281.

Farhan, M., Helmy, H., \& Afriyenti, M. (2019). Pengaruh Machiavellian dan love of money terhadap persepsi etika penggelapan pajak dengan religiusitas sebagai variabel moderasi (studi empiris pada wajib pajak di Kota Padang). Jurnal Eksplorasi Akuntansi, 1(1), 470-486.

Friscilla, Y., \& Nugroho, P. I. (2020). Love of money, machiavellian dan persepsi etis: Analisis berdasarkan perspektif gender. Jurnal Akuntansi Profesi, 11(2), 223-234.

Ghozali, I., \& Latan, H. (2015). Partial Least Squares : Konsep, Teknik dan Aplikasi Menggunakan Program SmartPLS 3.0 (2nd ed.). Badan Penerbit Universitas Dipenogoro Semarang.

Giovano, A., Wibowo, A. S., \& Yanuarisa, Y. (2020). Pengaruh love of money dan religiusitas terhadap kecenderungan fraud accounting dana desa dengan gender sebagai variabel moderasi pada desa di kecamatan Katingan Tengah. Jurnal Balance: Media Informasi Akuntansi Dan Kenangan, 12(2), 11-24.

Gu, H., \& Wen, Z. (2017). Structural validity of the Machiavellian Personality Scale: A bifactor exploratory structural equation modeling approach. Personality and Individual Differences, 105, 116-123.

Gurlek, M. (2021). Shedding light on the relationships between Machiavellianism, career ambition, and unethical behavior intention. Ethics \& Behavior, 31(1), 38-59. 
Hamdani, R., Rahimah, I., \& Hafiz, M. S. (2020). Exploring the Professionalism and Dysfunctional Behavior of Public Accountants on Audit Quality. Review of Integrative Business and Economics Research, 9(s3), 9-19. https:/ / search.proquest.com/docview/2386936624? accountid=17242

Hartono, J., \& Abdillah, W. (2015). Konsep dan Aplikeasi PLS (Partial Least Square) untuk Penelitian Empiris. BPFE Yogyakarta.

Jalil, I., Wahyuningsih, Y. E., \& Ansari, L. P. (2019). Applied of reasoned action theory (TRA) yang berdampak pada intention to purchase herbal cosmetics. Jurnal Bisnis Dan Kajian Strategi Manajemen, 3(2), 105-118.

Khan, S., Panatik, S. A., Saat, M. M., \& Perveen, H. (2013). Auditors' behavioral intention towards dysfunctional audit behavior applying theory of reasoned action. Jurnal Teknologi, 64(3), 153-158.

Khanifah, K., Isgiyarta, J., Lestari, I., \& Udin, U. (2019). The effect of gender, locus of control, love of money, and economic status on students' ethical perception. International Journal of Higher Education, 8(5), 168-175.

Korompis, C. W. M., \& Latjandu, L. D. (2017). Pengaruh narsisme klien, audit fee, independensi, skeptisme profesional dan interlock auditor eksternal terhadap audit judgement dalam pendeteksian kecurangan laporan keuangan (studi kasus pada KAP di Manado). Going Concern: Jurnal Riset Akuntansi, 12(2), 594-604.

Liu, B. C., \& Tang, T. L. P. (2011). Does the love of money moderate the relationship between public service motivation and job satisfaction? The case of Chinese professionals in the public sector. Public Administration Review, 71(5), 718-727. https://doi.org/10.1111/j.1540-6210.2011.02411.x

Nugraheni, H., \& Wahyuni, S. (2016). Pengaruh narsisme dan job stressor pada perilaku kerja kontra produktif dengan respon emosional negatif (anger) sebagai mediator. Jurnal Bisnis Dan Manajemen, 16(2), 49-66.

Pekdemir, I. M., \& Turan, A. (2015). The relationship among love of money, machiavellinism, and unethical behaviour. Canadian Social Science, 11(6), 48-59.

Prabowo, P. P., \& Widanaputra, A. A. G. P. (2018). Pengaruh love of money, machiavellian dan idealisme pada persepsi etis mahasiswa akuntansi. E-Jurnal Akuntansi, 23(1), 513-537.

Rindayanti, R., \& Budiarto, D. S. (2017). Hubungan Antara love of money, machiavellian dengan persepsi etis: Analisis berdasarkan perspektif gender. Akuntabilitas: Jurnal Ilmu Akuntansi, 10(2), 261-272.

Sumartono, Urumsah, D., \& Hamdani, R. (2020). Skills of the forensic accountants in revealing fraud in public sector: The case of Indonesia. Journal of Accounting and Investment, 21(1), 180-194. https://doi.org/10.18196/jai.2101144

Tang, T. L. P., \& Liu, H. (2012). Love of money and unethical behavior intention: Does an authentic supervisor's personal integrity and character (ASPIRE) make a difference? Journal of Business Ethics, 107(3), 295-312. https://doi.org/10.1007/s10551-011-1040-5

Yeltsinta, R., \& Fuad, F. (2013). Love of money, ethical reasoning, machiavellian, questionable actions: The impact on accounting students' ethical decision making by gender moderation. Diponegoro Journal of Accounting, 2(3), 713-723.

Yendrawati, R., \& Witono, W. (2011). Pengaruh sifat machiavellian, locus of control dan independensi terhadap perilaku etis auditor (studi empiris pada kantor akuntan publik di Yogyakarta). Jurnal Aplikasi Bisnis, 10(9), 10(9), 1233-1256. 